Prepared in cooperation with the

New York State Department of Environmental Conservation

\title{
Delineation of Areas Contributing Groundwater to Selected Receiving Surface Water Bodies for Long-Term Average Hydrologic Conditions From 1968 to 1983 for Long Island, New York
}

Scientific Investigations Report 2016-5138 



\section{Delineation of Areas Contributing Ground water to Selected Receiving Surface Water Bodies for Long-Term Average Hydrologic Conditions From 1968 to 1983 for Long Island, New York}

By Paul E. Misut and Jack Monti, Jr.

Prepared in cooperation with the

New York State Department of Environmental Conservation

Scientific Investigations Report 2016-5138 


\title{
U.S. Department of the Interior SALLY JEWELL, Secretary
}

\section{U.S. Geological Survey Suzette M. Kimball, Director}

\author{
U.S. Geological Survey, Reston, Virginia: 2016
}

For more information on the USGS - the Federal source for science about the Earth, its natural and living resources, natural hazards, and the environment-visit http://www.usgs.gov or call 1-888-ASK-USGS.

For an overview of USGS information products, including maps, imagery, and publications, visit http://store.usgs.gov.

Any use of trade, firm, or product names is for descriptive purposes only and does not imply endorsement by the U.S. Government.

Although this information product, for the most part, is in the public domain, it also may contain copyrighted materials as noted in the text. Permission to reproduce copyrighted items must be secured from the copyright owner.

Suggested citation:

Misut, P.E., and Monti, Jack, Jr., 2016, Delineation of areas contributing groundwater to selected receiving surface water bodies for long-term average hydrologic conditions from 1968 to 1983 for Long Island, New York: U.S. Geological Survey Scientific Investigations Report 2016-5138, 22 p., http://dx.doi.org/10.3133/sir20165138.

ISSN 2328-0328 (online) 


\section{Contents}

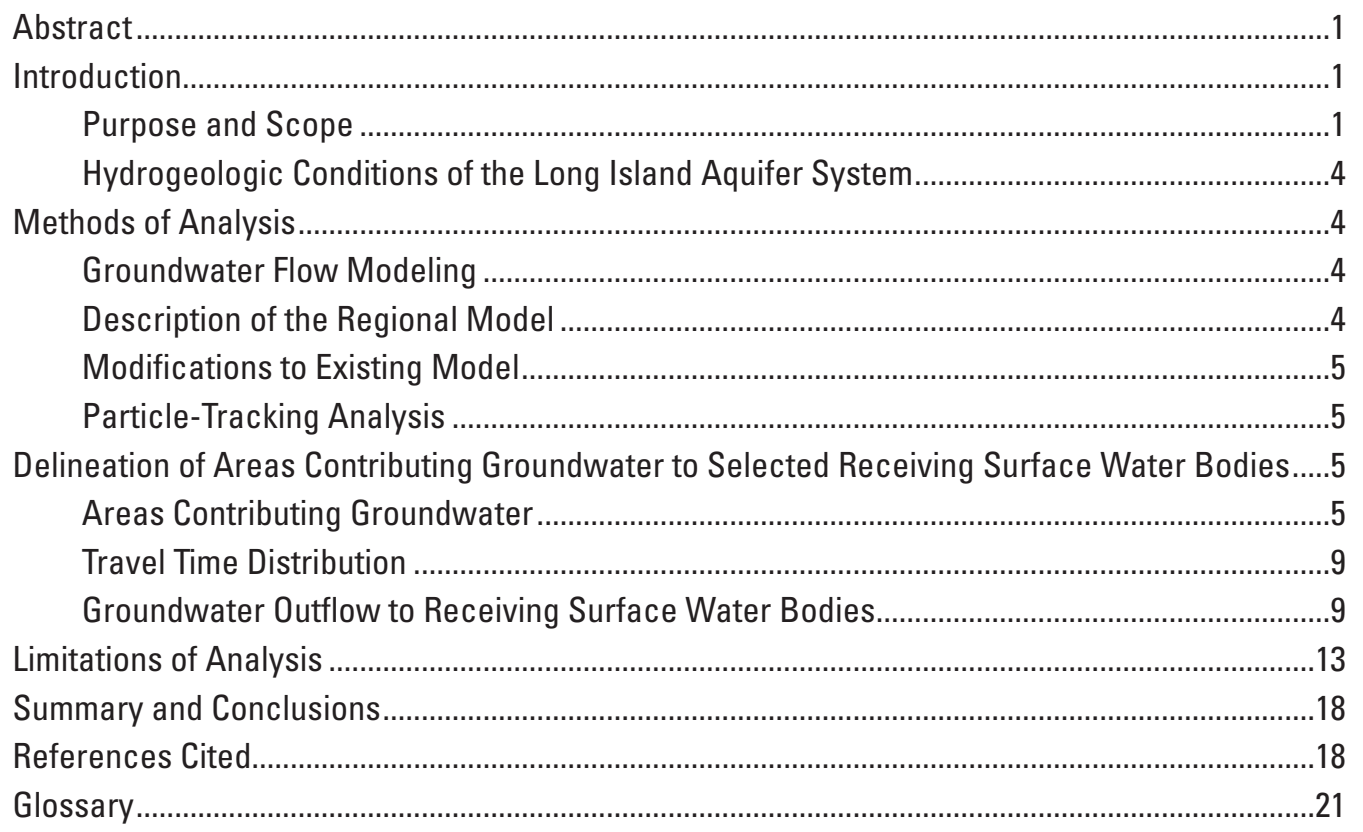

\section{Figures}

1. Map showing the groundwater-flow model grid of the regional flow model for $A$, western and $B$, eastern Long Island, New York.

2. Map showing areas contributing groundwater by type of receiving water body simulated by flow model of hydrologic conditions from 1968 to 1983 on $A$, western and $B$, eastern Long Island, New York

3. Map showing travel time simulated by flow model of hydrologic conditions from 1968 to 1983 on $A$, western and $B$, eastern Long Island, New York

4. Map showing areas contributing groundwater by type of receiving water body simulated by flow model of hydrologic conditions from 1968 to 1983 with particles stopping at weak sinks on $A$, western and $B$, eastern Long Island, New York

5. Map showing travel time simulated by flow model of hydrologic conditions from 1968 to 1983 with particles stopping at weak sinks on $A$, western and $B$, eastern Long Island, New York

\section{Tables}

1. Receiving water bodies on Long Island, New York.

2. Groundwater outflows to receiving water bodies simulated by flow model of hydrologic conditions from 1968 to 1983 for Long Island, New York. 


\section{Conversion Factors}

U.S. customary units to International System of Units

\begin{tabular}{lcl}
\hline \multicolumn{1}{c}{ Multiply } & By & \multicolumn{1}{c}{ To obtain } \\
\hline foot $(\mathrm{ft})$ & 0.3048 & meter $(\mathrm{m})$ \\
square mile $\left(\mathrm{mi}^{2}\right)$ & 2.590 & square kilometer $\left(\mathrm{km}^{2}\right)$ \\
million gallons $(\mathrm{Mgal})$ & 3,785 & cubic meter $\left(\mathrm{m}^{3}\right)$ \\
cubic foot per second $\left(\mathrm{ft}^{3} / \mathrm{s}\right)$ & 0.02832 & cubic meter per second $\left(\mathrm{m}^{3} / \mathrm{s}\right)$ \\
million gallons per day $(\mathrm{Mgal} / \mathrm{d})$ & 0.04381 & cubic meter per second $\left(\mathrm{m}^{3} / \mathrm{s}\right)$ \\
inch per year $(\mathrm{in} / \mathrm{yr})$ & 25.4 & millimeter per year $(\mathrm{mm} / \mathrm{yr})$ \\
foot per day $(\mathrm{ft} / \mathrm{d})$ & 0.3048 & meter per day $(\mathrm{m} / \mathrm{d})$ \\
\hline
\end{tabular}

\section{Datum}

Horizontal coordinate information was referenced to the North American Datum of 1983 (NAD 83).

Altitude, as used in this report, refers to distance above the vertical datum.

\section{Supplemental Information}

Wells on Long Island, New York are numbered serially by county. The number is prefixed by the first letter of the county name and suffixed by the well version; for example, well N6294.1 in Nassau County. Numbers are assigned in sequence by New York State as permits to drill are issued and have no relation to the location of wells within the county.

\section{Abbreviations}

$\begin{array}{ll}\text { MODFLOW } & \text { three-dimensional finite-difference groundwater-flow modeling software } \\ \text { MODPATH6 } & \text { particle-tracking analysis modeling software version } 6 \\ \text { NWO } & \text { National Water-Quality Program } \\ \text { NYSDEC } & \text { New York State Department of Environmental Conservation } \\ \text { USGS } & \text { U.S. Geological Survey }\end{array}$




\title{
Delineation of Areas Contributing Groundwater to Selected Receiving Surface Water Bodies for Long-Term Average Hydrologic Conditions from 1968 to 1983 for Long Island, New York
}

\author{
By Paul E. Misut and Jack Monti, Jr.
}

\begin{abstract}
To assist resource managers and planners in developing informed strategies to address nitrogen loading to coastal water bodies of Long Island, New York, the U.S. Geological Survey and the New York State Department of Environmental Conservation initiated a program to delineate a comprehensive dataset of groundwater recharge areas (or areas contributing groundwater), travel times, and outflows to streams and saline embayments on Long Island. A four-layer regional threedimensional finite-difference groundwater-flow model of hydrologic conditions from 1968 to 1983 was used to provide delineations of 48 groundwater watersheds on Long Island. Sixteen particle starting points were evenly spaced within each of the 4,000- by 4,000-foot model cells that receive water-table recharge and tracked using forward particletracking analysis modeling software to outflow zones. For each particle, simulated travel times were grouped by age as follows: less than or equal to 10 years, greater than 10 years and less than or equal to 100 years, greater than 100 years and less than or equal to 1,000 years, and greater than 1,000 years; and simulated ending zones were grouped into 48 receiving water bodies, based on the New York State Department of Environmental Conservation Waterbody Inventory/Priority Waterbodies List. Areal delineation of travel time zones and groundwater contributing areas were generated and a table was prepared presenting the sum of groundwater outflow for each area.
\end{abstract}

\section{Introduction}

The coastal water bodies (fig. 1) of Long Island, New York, are important economic and recreational resources for the region. In addition to tidal exchanges of saltwater, coastal water bodies receive freshwater from inflow of both surface water and groundwater. Marine and estuarine ecosystems are adversely affected by excessive nitrogen inputs associated with development and urbanization in the freshwater recharge areas to coastal water bodies. Increases in nitrogen, which originate from anthropogenic sources such as wastewater and fertilizers, can cause eutrophication in coastal water bodies. Eutrophication is associated with enhanced growth of undesirable algae and the loss of important marine habitats. As of 2016, eutrophication has adversely affected various coastal water bodies on Long Island, including an increase in the magnitude and frequency of algal blooms, a decrease in water clarity, and a loss of eelgrass beds.

Communities on Long Island are taking measures to mitigate the discharge of nitrogen within the areas where coastal water bodies are at risk for nitrogen-related eutrophication. In cooperation with the U.S. Geological Survey (USGS), the New York State Department of Environmental Conservation (NYSDEC) has initiated a program to delineate a comprehensive dataset of groundwater recharge areas, travel times ${ }^{1}$, and outflows to Long Island streams and saline embayments. This information is beneficial for developing informed strategies to address nutrient loading to these systems, to provide the basis for further scientific study, and to engage the public. As part of the first phase of the program, the USGS used a regional MODFLOW-2005 (Harbaugh, 2005) model of hydrologic conditions from 1968 to 1983 (Buxton and Smolensky, 1999) to coarsely delineate a set of 48 groundwater-recharge areas (called areas contributing groundwater in this report) to streams and saline embayments on Long Island. Delineating groundwater-recharge areas under the flow regimes prevalent on Long Island requires evaluation of three-dimensional groundwater-flow patterns in the aquifer.

\section{Purpose and Scope}

This report presents the results of a particle-tracking analysis $^{1}$ of a regional groundwater flow model for Long Island to delineate areas contributing groundwater and travel times, differentiate outflow to saline water bodies from that to freshwater bodies, and calculate groundwater outflows to each

${ }^{1}$ Terms in italic are defined in the glossary. 


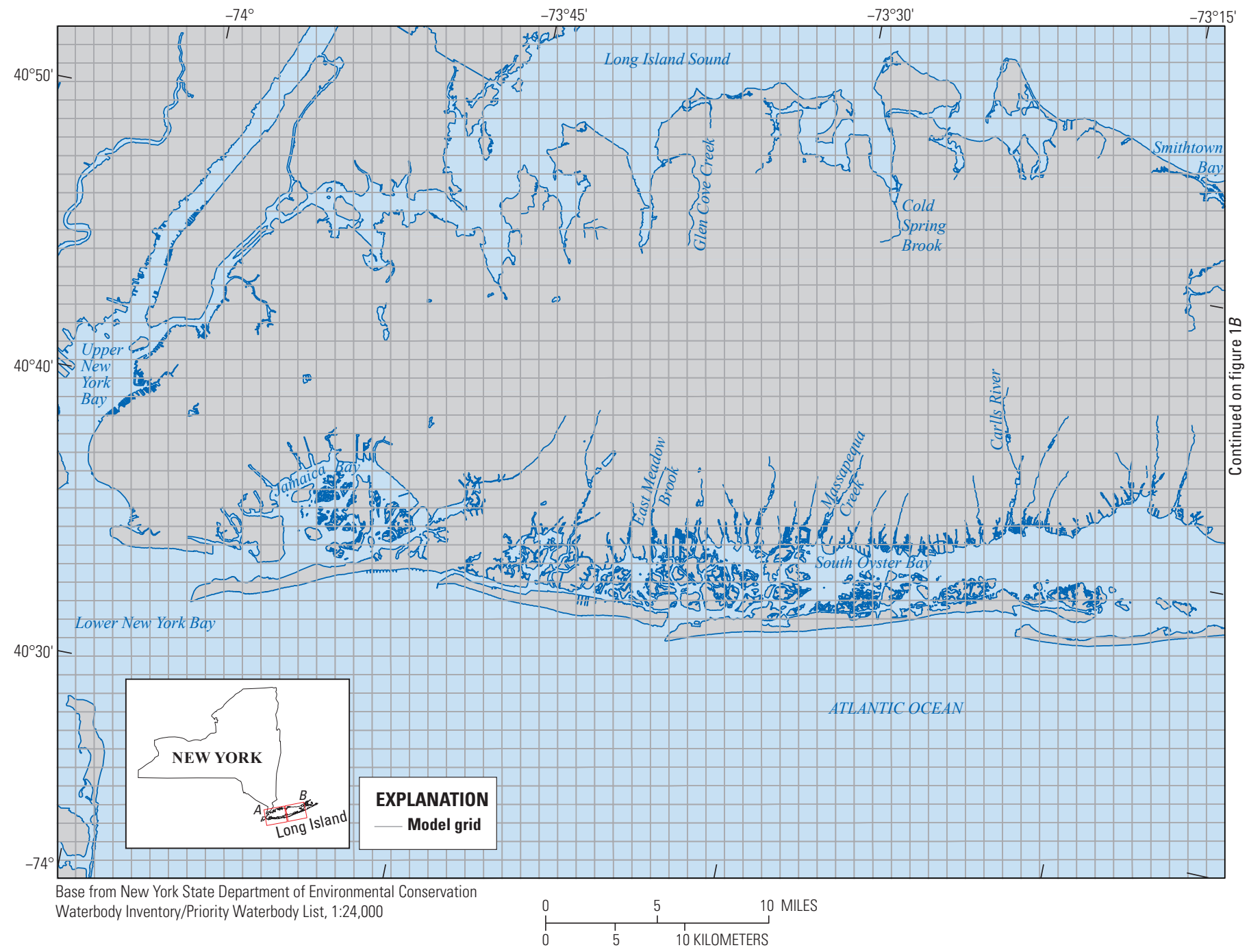

Figure 1. The groundwater-flow model grid of the regional flow model for $A$, western and $B$, eastern Long Island, New York. Entire map in full scale available for download at http://dx.doi.org/10.3133/sir20165138. 


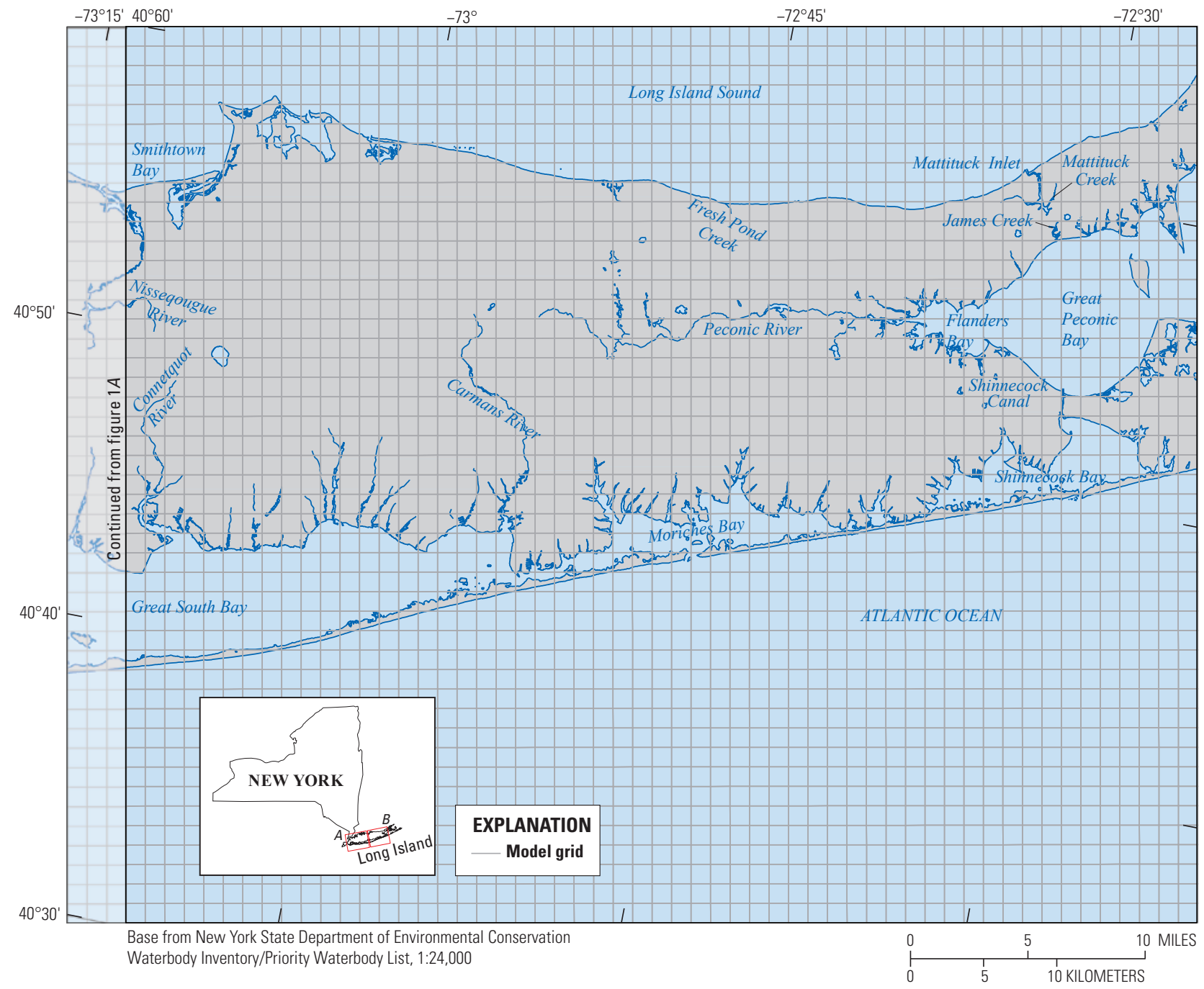

Figure 1. The groundwater-flow model grid of the regional flow model for $A$, western and $B$, eastern Long Island, New York. Entire map in full scale available for download at http://dx.doi.org/10.3133/sir20165138.—Continued 
individual surface-water body through the use of the regional groundwater model for Long Island for long-term average conditions from 1968 to 1983 (Buxton and Smolensky, 1999). This report also provides an analysis of the effects of different particle-tracking methods on delineation of areas contributing groundwater. A model archive was also prepared and includes binary input and output files, computer program executables, source codes, and geographic information system (GIS) shapefiles (Misut and Monti, 2016).

\section{Hydrogeologic Conditions of the Long Island Aquifer System}

The Long Island aquifer system is a 1,400-square mile wedge-shaped mass of saturated unconsolidated deposits that overlie nearly impermeable consolidated bedrock and attain a maximum thickness of about 2,000 feet. The boundaries of the fresh groundwater reservoir are the water table, the freshwater/saltwater interfaces, the bedrock surface, and streams. A generalized schematic diagram of the flow is shown in DeSimone and others (2014). The estimated volume of material saturated with fresh groundwater is about 180 cubic miles. The water levels, water quality and other hydrogeologic conditions on Long Island are listed in U.S. Geological Survey (2016). Water from precipitation recharges the aquifer and then flows through the aquifer to the receiving surfacewater body - a pond, stream, or coastal water body — or to a pumped well. The area at the water table through which water recharges and ultimately flows out to a specific surface-water body is the area contributing groundwater to that surfacewater body. In groundwater-dominated systems, such as that on Long Island, surface drainages that are defined by topography cannot be used to delineate areas that contribute water to a surface-water body. Instead, it is best to use the areas contributing groundwater because the majority of water entering the surface-water body is sourced from the groundwater system.

Hydrogeologic conditions on Long Island determine length of particle pathways and time of travel. For example, in the glacial outwash plain of the southern shore, groundwater typically would move more rapidly than in glacial morainal areas along the northern shore because outwash has higher hydraulic conductivity (about $250 \mathrm{ft} / \mathrm{d}$ ) than morainal deposits (about $100 \mathrm{ft} / \mathrm{d}$ ). Rates of groundwater flow are directly correlated to the hydraulic conductivity.

\section{Methods of Analysis}

Particle-tracking methods were applied to a modified USGS regional flow model for Long Island from Buxton and Smolensky (1999) that represents hydrologic conditions from 1968 to 1983 at a coarse model-grid scale. The particletracking algorithm MODPATH version 6 (Pollock, 2012) hereafter, referred to as MODPATH, was used to simulate advective transport in the aquifer, to delineate the areas at the water table that contribute groundwater to coastal and freshwater bodies, and to estimate total travel times of groundwater from the water table to outflow. Cell-by-cell flow information from the groundwater flow model simulations was used in MODPATH to calculate flow-velocity vectors within model cells. The postprocessing software suite ModelMuse (Winston, 2009) was used to convert information from the models and MODPATH to georeferenced data layers that can be used in a GIS.

\section{Groundwater Flow Modeling}

The MODFLOW-2005 code (Harbaugh, 2005) solves the groundwater flow equation using finite difference techniques. The governing partial differential equation is as follows:

$$
S_{s} \frac{\partial h}{\partial t}=\frac{\partial}{\partial x}\left[K_{x x} \frac{\partial h}{\partial x}\right]+\frac{\partial}{\partial y}\left[K_{y y} \frac{\partial h}{\partial y}\right]+\frac{\partial}{\partial z}\left[K_{z z} \frac{\partial h}{\partial z}\right]+W,
$$

where

$$
\begin{aligned}
S_{s} & \text { is the specific storage of the porous material, } \\
t & \text { is time, } \\
K_{x x}, K_{y y}, K_{z z} & \text { are the values of hydraulic conductivity along } \\
& \text { the } x, y, \text { and } z \text { coordinate axes, } \\
h & \text { is the potentiometric head, and } \\
W & \text { is a volumetric } \text { flux per unit volume } \\
& \text { representing sources and (or) sinks of } \\
& \text { water. }
\end{aligned}
$$

\section{Description of the Regional Model}

The regional groundwater flow model for Long Island (Buxton and Smolensky, 1999) was developed to simulate long-term average (steady-state) pumping and recharge conditions representative for the period from 1968 to 1983 for the main body of Long Island west of Shinnecock Canal and Mattituck and James Creeks (fig. 1). Groundwater-flow analyses that incorporated the framework and (or) results from the regional groundwater flow model include Camp Dresser \& McKee Inc. (2003) and Masterson and others (2016).

In the regional groundwater flow model for Long Island, four model layers with distributed transmissivity values are used to represent the three main Long Island aquifers: upper glacial, Magothy, and Lloyd. Between model layers, distributed vertical-conductance terms are used to implicitly represent confining units. Simulated recharge from infiltration of precipitation and returned water is represented by constant flux boundaries. Simulated outflow to shoreline and subsea areas is represented by constant head boundaries, and outflow to pumping wells and freshwater base flow to streams is represented by constant flux boundaries (Buxton and Smolensky, 1999). Long-term average (steady-state) pumping stresses for the period from 1968 to 1983 were also represented (Buxton and Smolensky, 1999). 


\section{Modifications to Existing Model}

To facilitate use for the analysis in this report, a series of modifications and updates were made to the Buxton and Smolensky (1999) regional groundwater flow model for Long Island. MODFLOW-2005 (Harbaugh, 2005), a finitedifference formulation of the groundwater flow equation and MODPATH version 6 (Pollock, 2012) codes have replaced the original versions of the codes, but have retained the core model aquifer properties, boundaries, and stresses in the "Description of the Regional Model" section of this report and as given by Buxton and Smolensky (1999). By using MODFLOW-2005, it was also possible to implement the ModelMuse open-source graphical user interface of Winston and others (2009). The original and modified models yielded slightly different simulated water budgets and particle-tracking results, which may be due to corruption of input files of the 1999 model. An attempt was made to rectify the differences through trial-and-error until a reasonable match was made between the composite budgets from the 1999 model and the current model and with the particle tracking output given in (Buxton and Smolensky, 1999) and herein. There was a total of 0.09 percent difference between the total budgets (in and out); this difference stemmed from differences in constant head cells between the Buxton model and this current model. The time-variant constant head package (Harbaugh and others, 2000) was implemented using constant head altitudes of Buxton and Smolensky (1999) and produces a new separate file of constant head specifications. The particle pathways were qualitatively matched by comparing the output from Buxton and others (1991) and this current model. The porosity is a uniformly-distributed value of 30 percent in all original and modified models including (Buxton and others, 1991).

\section{Particle-Tracking Analysis}

Following the approach of Buxton and others (1991), the particle-tracking algorithm of MODPATH (Pollock, 2012) was used to simulate advective transport in the aquifers, to delineate the areas at the water table that contribute water to coastal and freshwater bodies, and to estimate the total travel time of water from the water table to outflow locations. Cell-by-cell flow information from the groundwater model simulations was used in MODPATH to calculate flowvelocity vectors within model cells. Buxton and others (1991) converted the implicit representation of confining units used in MODFLOW to an explicit representation with vertical hydraulic conductivity and confining bed thicknesses terms and converted the transmissivity of the aquifer layers to hydraulic conductivity and thickness. The same approach was followed for the particle tracking analysis in this study. The paths of particles with forward-tracked motion started at the water table and terminated at outflow boundaries, with total travel time recorded for each particle. Polygons were generated of particle starting points coded by termination index and total travel time for each receiving surface water body. The polygons were further subdivided into travel-time regions of tracking times from 0 to 10 years, 10 to 100 years, 100 to 1,000 years, and greater than 1,000 years.

For the purpose of this analysis, water particle paths were not terminated at all model cells that represented receiving surface water bodies. Instead, water particle paths only terminated in cells in which 100 percent of the groundwater flow that enters the cell outflows to a surface-water body, called a strong sink cell. Model cells where less than 100 percent of the total inflow to a cell outflows to the surface-water body (some water goes beneath the surface-water body or travels through the cell to a neighboring cell) are called weak sinks.

\section{Delineation of Areas Contributing Groundwater to Selected Receiving Surface Water Bodies}

The size and shape of areas contributing groundwater (listed in table 1) are a function of the amount of outflow to the receiving water body, the hydraulic properties of the groundwater flow model, the geometry of the coast, the locations of ponds and streams, and the discretization of the model. For this steady-state model, the area at the water table times the recharge rate approximates the total amount of water leaving at receiving surface water bodies.

\section{Areas Contributing Groundwater}

Particle-tracking analysis for delineation of areas contributing groundwater was conducted with strong-sink particle terminations (shown in fig. 2). The majority of particles that were released at the water table that did not reach receiving surface water bodies were captured by public-supply wells. Freshwater stream receptors are indicated by positive indices, and negative indices indicate discharge to saline coastal water bodies (fig. 2). Areas contributing groundwater to saline water bodies likely have a lumped outflow of both saline water and freshwater outflow types. Due to the coarse nature of the model grid, in most lumped outflow areas contributing groundwater, the majority of outflow occurs at the saline water body, not to the freshwater tributaries.

Saline coastal surface-water body receptors may be subdivided into shallow and deep zones that receive groundwater outflow. Shallow zones occur where fresh groundwater flows laterally from the upper glacial aquifer or upward from the Magothy aquifer (or Jameco aquifer where present) to mix with overlying saline groundwater within the Gardiners clay confining unit and the upper glacial aquifer. Deep zones occur where fresh groundwater outflows offshore from the Lloyd aquifer to mix with overlying saline groundwater within the Raritan confining unit and the Magothy and (or) Jameco aquifer. The areas that contribute 


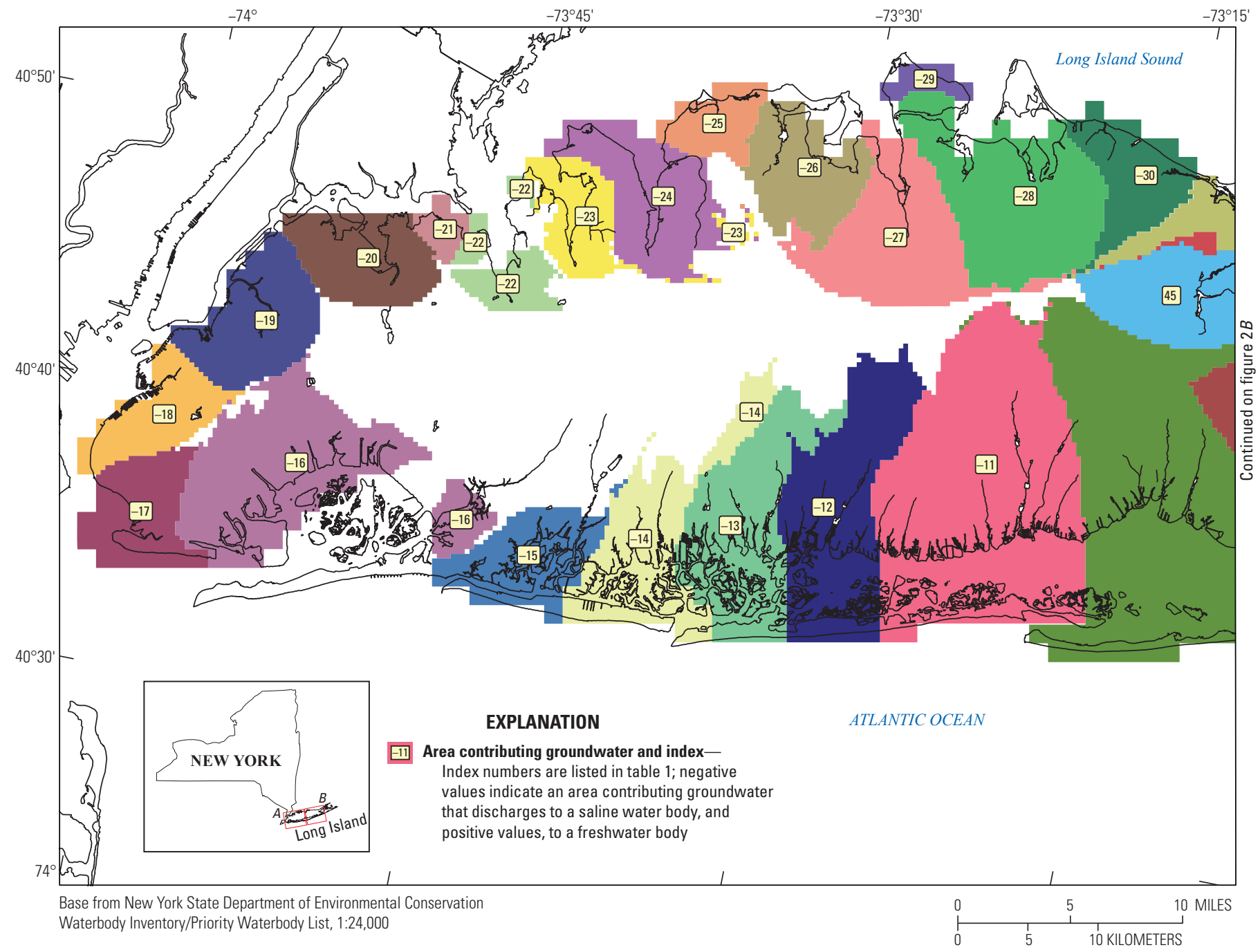

Figure 2. Areas contributing groundwater by type of receiving water body simulated by flow model of hydrologic conditions from 1968 to 1983 on $A$, western and $B$, eastern Long Island, New York. Entire map in full scale available for download at http://dx.doi.org/10.3133/ sir20165138. 


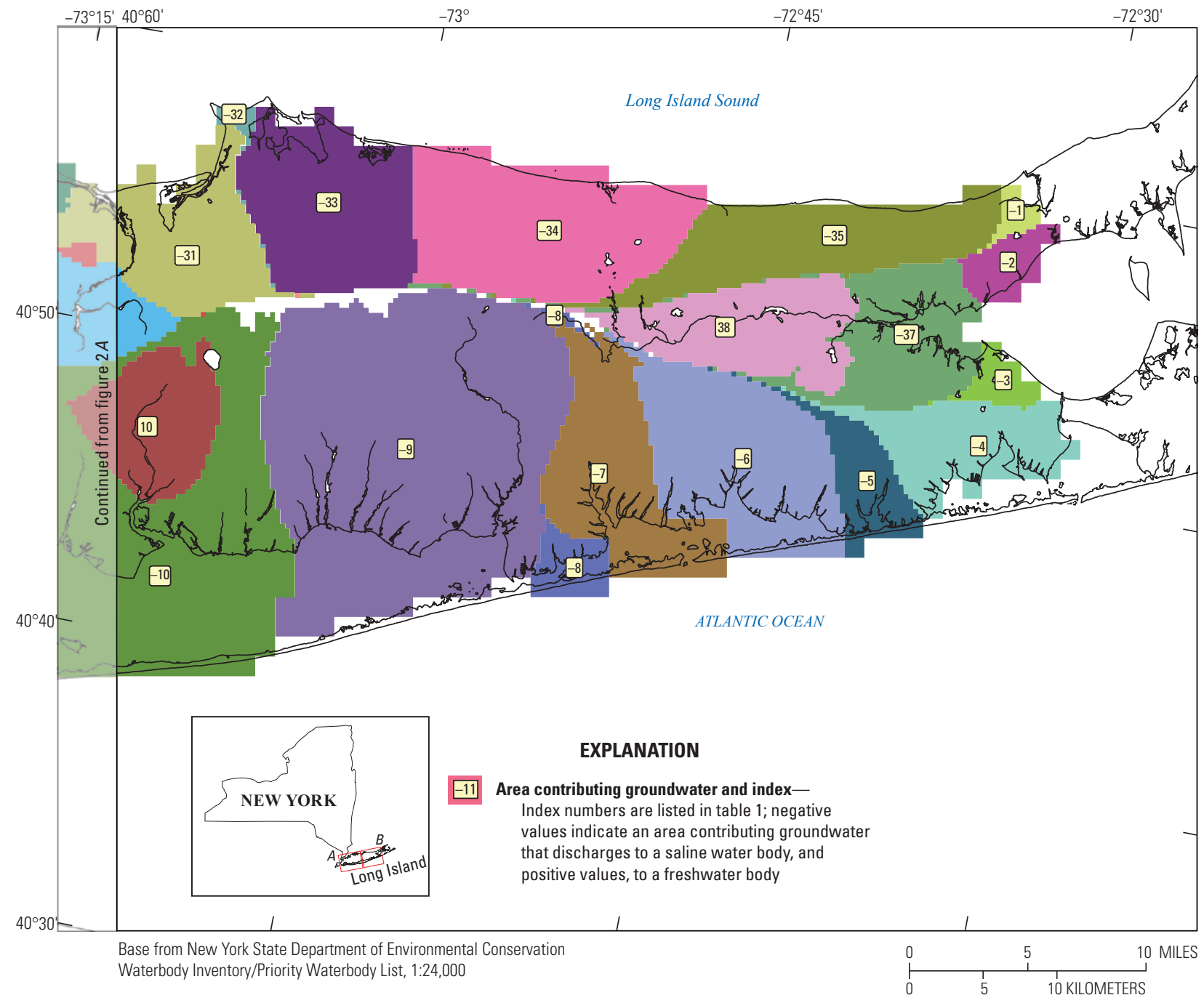

Figure 2. Areas contributing groundwater by type of receiving water body simulated by flow model of hydrologic conditions from 1968 to 1983 on $A$, western and $B$, eastern Long Island, New York. Entire map in full scale available for download at http://dx.doi.org/10.3133/sir20165138.—Continued 
Table 1. Receiving water bodies on Long Island, New York.

[Freshwater bodies are listed in italic. WI/PWL, New York State Department of Environmental Conservation Waterbody Inventory/Priority Waterbody List]

\begin{tabular}{|c|c|}
\hline Index & WI/PWL name \\
\hline 1 & Mattituck Inlet/Cr, Low, and tidal tribs; and Long Island Sound, Suffolk Co, Central \\
\hline 2 & Tidal Tribs to Gr Peconic Bay, Northshr; and Great Peconic Bay and minor coves \\
\hline 4 & Shinnecock Bay (and Inlet) \\
\hline 5 & Quantuck Canal/Moneybogue Bay; Quantuck Bay; and Quogue Canal \\
\hline 6 & Tuthill, Harts, Seatuck Coves; and Moriches Bay, East \\
\hline 8 & Tidal Tribs to Narrow Bay; and Narrow Bay \\
\hline 9 & Patchogue Bay; Bellport Bay and Great South Bay, East \\
\hline 10 & Great Cove; Nicoll Bay; and Great South Bay, Middle \\
\hline 11 & Great South Bay, West \\
\hline 12 & South Oyster Bay \\
\hline 16 & Jamaica Bay, Eastern and Western, and tribs (Brooklyn and Queens) \\
\hline 17 & Coney Island Creek; and Lower New York Bay/Gravesend Bay \\
\hline 18 & Gowanus Canal; Erie Basin; and Upper New York Bay \\
\hline 19 & Newtown Creek and tidal tribs; and East River, Lower \\
\hline 20 & Flushing Creek/Bay; Minor Tribs to Upper East River; and East River, Upper \\
\hline 21 & East River, Upper from Whitestone Br to Throgs Neck Br, Queens \\
\hline 22 & Alley Creek/Little Neck Bay Trib; Little Neck Bay; and Long Island Sound, Western Portion \\
\hline 23 & Manhasset Bay, and tidal tribs \\
\hline 24 & Glen Cove Creek, Lower, and tribs; and Hempstead Harbor, and tidal tribs \\
\hline 25 & Dosoris Pond; West Pond and Long Island Sound, Nassau County Waters \\
\hline 32 & Flax Pond \\
\hline 33 & $\begin{array}{l}\text { Conscience Bay; Port Jefferson Harbor, North; Setauket Harbor; Mt Sinai Harbor and tidal tribs to Long Island Sound, Suffolk Co, } \\
\text { Central }\end{array}$ \\
\hline 34 & Wading River, Lower, and tidal tribs to Long Island Sound, Suffolk Co, Central from Miller place beach to Camp Baiting Hollow \\
\hline 35 & Long Island Sound, Suffolk Co, Central from Fresh Pond Creek to Mattituck Hills \\
\hline 37 & Peconic River, Lower, and tidal tribs; Flanders Bay, West/Lower Sawmill Creek; and Flanders Bay, East/Center, and tribs \\
\hline 38 & Peconic River \\
\hline 39 & Carmans River \\
\hline 40 & Patchogue River \\
\hline 41 & Connetquot River \\
\hline 42 & East Meadow Brook \\
\hline 43 & Glen Cove Creek \\
\hline 44 & Cold Spring Brook \\
\hline 45 & Nissequogue River \\
\hline 46 & Carlls River \\
\hline 47 & Massapequa Creek \\
\hline 48 & Bellmore Creek \\
\hline
\end{tabular}


recharge to these deep zones were omitted from the delineated areas contributing groundwater because the associated minimum ground-water age exceeds 1,000 years and the area comprises less than 3 percent of the total recharge area of Long Island.

Selected receiving surface water bodies were obtained from the NYSDEC Waterbody Inventory/Priority Waterbodies List (New York State Department of Environmental Conservation, 2009). Given the coarse model-grid discretization (4,000-foot cell size), many of the small fresh surface water bodies listed on the NYSDEC Waterbody Inventory/Priority Waterbodies List were aggregated and included as part of areas contributing groundwater to a larger receiving saline water body. Although termination boundaries were defined for streams draining to fresh surfacewater bodies (table 1, indices 38-48), many of these were weak sinks, and the simulation had only three resulting areas contributing groundwater with base flow to freshwater bodies: the Connetquot River (index 41) and adjacent streams tributary to central Great South Bay (index 10), the Peconic River (index 38), and the Nissequogue River (index 45). Areas contributing ground-water to the Carmans River (index 39) and the other freshwater bodies identified in table 1 were not delineated because particles pass through these features due to these water bodies acting as weak sinks. In other words, only some of the outflow of weak sinks exits at the boundary condition; the rest of the flows are through the sides of model cell.

Near a stressed reach of the Jamaica Bay coastline, groundwater does not flow out to saline receiving water boundaries but instead flows toward public-supply wells; thus, there is a gap in the corresponding areas contributing groundwater of index 16 (fig. $2 A$ ). In the simulation, particles are allowed to flow through weak-sink outflow boundary cells (that is, cells with partial throughput of water).

\section{Travel Time Distribution}

Different travel times from the water table to outflow location are due to different flow patterns in the aquifers and vary based on multiple components. Groundwater that flows through shallow parts of the aquifer has a shorter travel time to outflow locations than water that recharges the aquifer at greater distances from these locations and that flows deeper in the aquifer before outflowing. Differences in travel time through the aquifer have important effects on nitrogen attenuation within the aquifer because subsurface attenuation processes are time dependent. Knowledge of groundwater travel times may be useful in the assessment of nitrogen loads to coastal water bodies if subsurface attenuation mitigates the amount of nitrogen originating from a source area that reaches an estuary.

Travel times in the Long Island aquifers range from days (in areas where the recharge areas are near outflow locations) to more than 1,000 years (near groundwater divides, which are areas generally at greater distances from outflow locations). The locations of natural hydrologic boundaries (ponds, streams, and coastal water bodies) and regional groundwater divides affect the regional pattern of travel times. Travel times of particles from starting locations to points of outflow are presented in figure 3. GIS polygons were formed from areas of similar travel time (Particle-tracking Analysis section). In regions of fast moving groundwater, such as the glacial outwash plain of the southern shore, travel times are faster than in regions where groundwater moves more slowly, such as glacial moraine areas along the northern shore; thus the travel time areas are generally larger on the southern side of Long Island than the northern side of Long Island (yellow and pink bands in fig. 3 are thicker).

\section{Groundwater Outflow to Receiving Surface Water Bodies}

Simulated groundwater outflows to receiving surface water bodies are listed in table 2. Water bodies such as the Long Island Sound west of Mattituck (index 1) do not include fresh surface-water features and therefore represent zero freshwater outflow sums. Areas contributing groundwater to freshwater streams do not include a saline water body and, therefore, represent zero saline water outflow sums. 


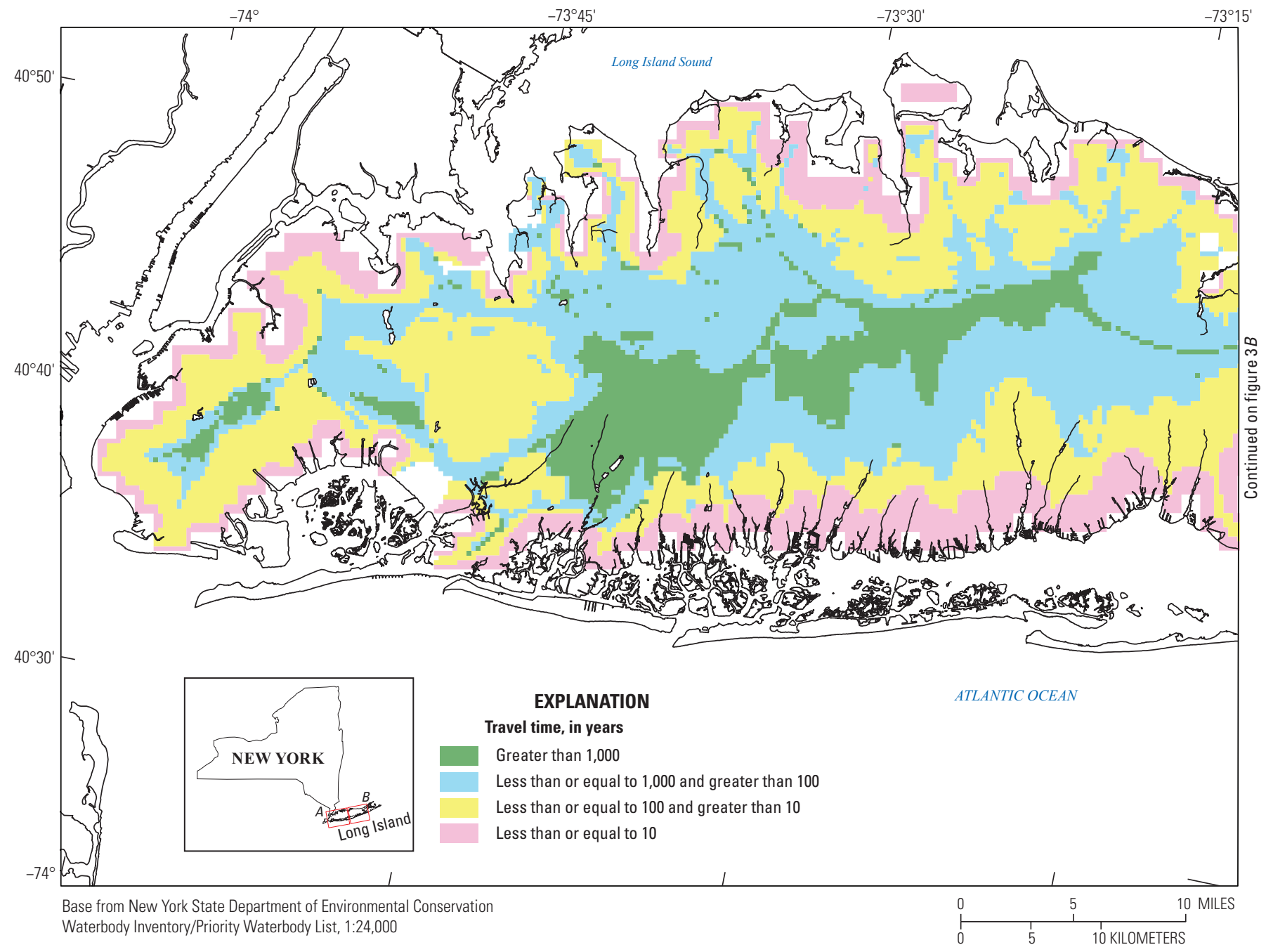

Figure 3. Travel time simulated by flow model of hydrologic conditions from 1968 to 1983 on $A$, western and $B$, eastern Long Island, New York. Entire map in full scale available for download at http://dx.doi.org/10.3133/sir20165138. 


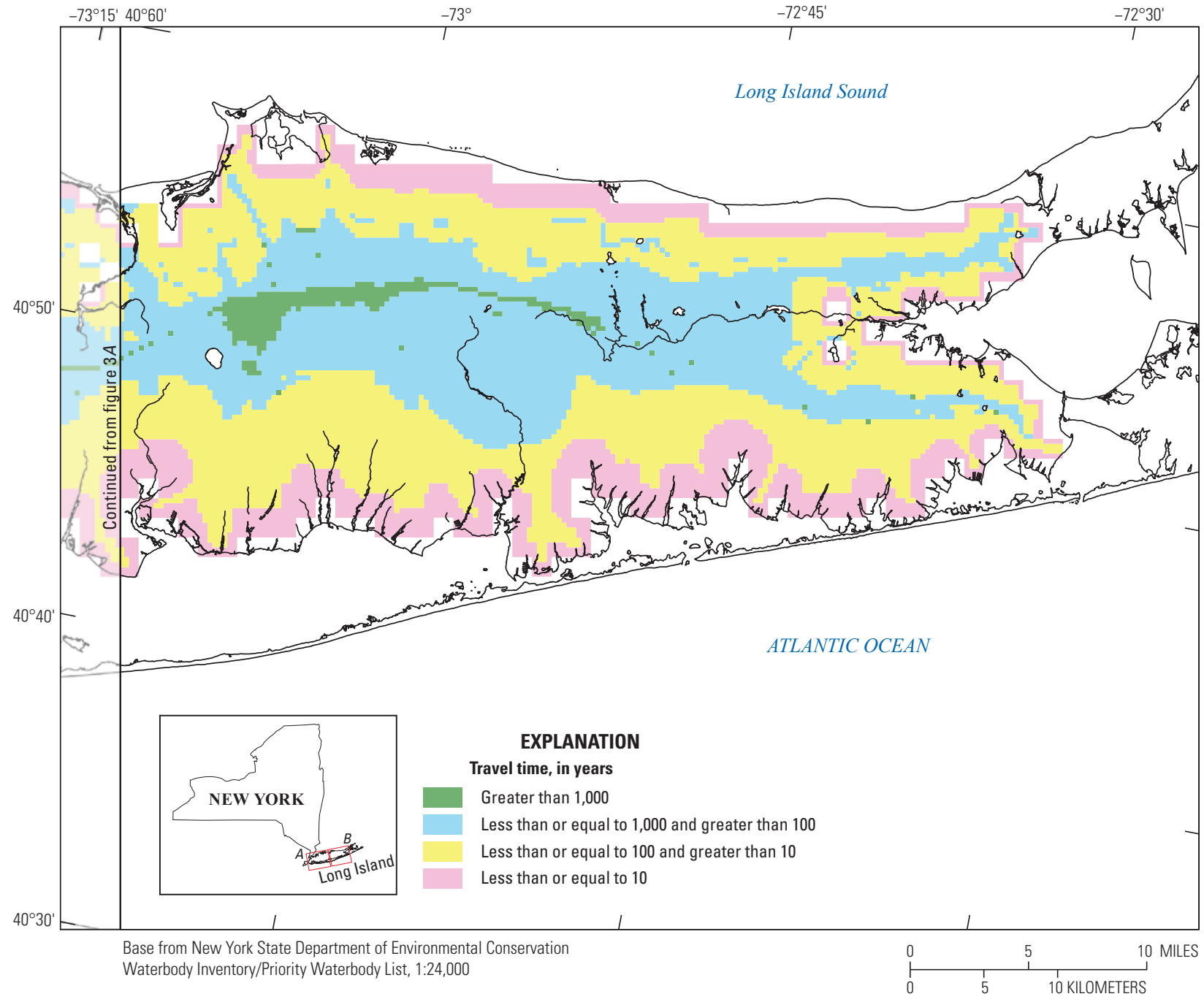

Figure 3. Travel time simulated by flow model of hydrologic conditions from 1968 to 1983 on $A$, western and $B$, eastern Long Island, New York. Entire map in full scale available for download at http://dx.doi.org/10.3133/sir20165138. - Continued 
Table 2. Groundwater outflows to receiving water bodies simulated by flow model of hydrologic conditions from 1968 to 1983 for Long Island, New York.

[Outflow sums are in cubic feet per day. Freshwater body names are listed in italic. WI/PWL, New York State Department of Environmental Conservation Waterbody Inventory/Priority Waterbody List; $\left.\mathrm{E}+[\mathrm{x}], \times 10^{\mathrm{x}}\right]$

\begin{tabular}{|c|c|c|c|}
\hline \multirow[t]{2}{*}{ Index } & \multirow[t]{2}{*}{ WI/PWL name } & \multicolumn{2}{|c|}{$\begin{array}{l}\text { Sum of outflow by } \\
\text { receiving water body type }\end{array}$} \\
\hline & & Saline & Freshwater \\
\hline 1 & Mattituck Inlet/Cr, Low, and tidal tribs; and Long Island Sound, Suffolk Co, Central & $1.59 \mathrm{E}+05$ & $0.00 \mathrm{E}+00$ \\
\hline 2 & Tidal Tribs to Gr Peconic Bay, Northshr; and Great Peconic Bay and minor coves & $5.07 \mathrm{E}+05$ & $0.00 \mathrm{E}+00$ \\
\hline 3 & Red Creek Pond and tidal tribs; Squire Pond and tribs; and Great Peconic Bay and minor coves & $4.46 \mathrm{E}+05$ & $0.00 \mathrm{E}+00$ \\
\hline 4 & Shinnecock Bay (and Inlet) & $2.20 \mathrm{E}+06$ & $1.12 \mathrm{E}+05$ \\
\hline 7 & Forge River, Lower and Cove; and Moriches Bay, West & $2.47 \mathrm{E}+06$ & $1.01 \mathrm{E}+06$ \\
\hline 8 & Tidal Tribs to Narrow Bay; and Narrow Bay & $4.69 \mathrm{E}+05$ & $4.93 \mathrm{E}+04$ \\
\hline 9 & Patchogue Bay; Bellport Bay and Great South Bay, East & $4.58 \mathrm{E}+06$ & $2.95 \mathrm{E}+06$ \\
\hline 10 & Great Cove; Nicoll Bay; and Great South Bay, Middle & $5.88 \mathrm{E}+06$ & $4.92 \mathrm{E}+06$ \\
\hline 11 & Great South Bay, West & $3.71 \mathrm{E}+06$ & $3.67 \mathrm{E}+06$ \\
\hline 16 & Jamaica Bay, Eastern and Western, and tribs (Brooklyn and Queens) & $2.80 \mathrm{E}+06$ & $5.30 \mathrm{E}+05$ \\
\hline 17 & Coney Island Creek; and Lower New York Bay/Gravesend Bay & $5.76 \mathrm{E}+05$ & $0.00 \mathrm{E}+00$ \\
\hline 18 & Gowanus Canal; Erie Basin; and Upper New York Bay & $7.21 \mathrm{E}+05$ & $2.50 \mathrm{E}+04$ \\
\hline 19 & Newtown Creek and tidal tribs; and East River, Lower & $1.48 \mathrm{E}+06$ & $4.32 \mathrm{E}+04$ \\
\hline 20 & Flushing Creek/Bay; Minor Tribs to Upper East River; and East River, Upper & $1.29 \mathrm{E}+06$ & $7.76 \mathrm{E}+05$ \\
\hline 21 & East River, Upper from Whitestone Br to Throgs Neck Br, Queens & $2.12 \mathrm{E}+05$ & $0.00 \mathrm{E}+00$ \\
\hline 22 & Alley Creek/Little Neck Bay Trib; Little Neck Bay; and Long Island Sound, Western Portion & $9.65 \mathrm{E}+05$ & $4.16 \mathrm{E}+05$ \\
\hline 23 & Manhasset Bay, and tidal tribs & $1.04 \mathrm{E}+06$ & $2.54 \mathrm{E}+05$ \\
\hline 24 & Glen Cove Creek, Lower, and tribs; and Hempstead Harbor, and tidal tribs & $2.52 \mathrm{E}+06$ & $2.33 \mathrm{E}+04$ \\
\hline 25 & Dosoris Pond; West Pond and Long Island Sound, Nassau County Waters & $9.20 \mathrm{E}+05$ & $4.46 \mathrm{E}+04$ \\
\hline 26 & Mill Neck Creek and tidal tribs; and Oyster Bay Harbor & $1.69 \mathrm{E}+06$ & $6.84 \mathrm{E}+05$ \\
\hline 34 & $\begin{array}{l}\text { Wading River, Lower, and tidal tribs to Long Island Sound, Suffolk Co, Central from Miller place beach } \\
\text { to Camp Baiting Hollow }\end{array}$ & $6.29 \mathrm{E}+06$ & $6.28 \mathrm{E}+04$ \\
\hline 35 & Long Island Sound, Suffolk Co, Central from Fresh Pond Creek to Mattituck Hills & $3.57 \mathrm{E}+06$ & $0.00 \mathrm{E}+00$ \\
\hline 36 & Unassigned & & \\
\hline 37 & $\begin{array}{l}\text { Peconic River, Lower, and tidal tribs; Flanders Bay, West/Lower Sawmill Creek; and Flanders Bay, } \\
\text { East/Center, and tribs }\end{array}$ & $2.56 \mathrm{E}+06$ & $0.00 \mathrm{E}+00$ \\
\hline 38 & Peconic River & $0.00 \mathrm{E}+00$ & $4.77 \mathrm{E}+06$ \\
\hline 39 & Carmans River & $0.00 \mathrm{E}+00$ & $5.48 \mathrm{E}+06$ \\
\hline 40 & Patchogue River & $0.00 \mathrm{E}+00$ & $1.36 \mathrm{E}+06$ \\
\hline 41 & Connetquot River & $0.00 \mathrm{E}+00$ & $2.92 \mathrm{E}+06$ \\
\hline 42 & East Meadow Brook & $0.00 \mathrm{E}+00$ & $9.11 \mathrm{E}+05$ \\
\hline 43 & Glen Cove Creek & $0.00 \mathrm{E}+00$ & $3.16 \mathrm{E}+05$ \\
\hline 44 & Cold Spring Brook & $0.00 \mathrm{E}+00$ & $2.16 \mathrm{E}+05$ \\
\hline 45 & Nissequogue River & $0.00 \mathrm{E}+00$ & $4.42 \mathrm{E}+06$ \\
\hline 46 & Carlls River & $0.00 \mathrm{E}+00$ & $1.78 \mathrm{E}+06$ \\
\hline 47 & Massapequa Creek & $0.00 \mathrm{E}+00$ & $1.04 \mathrm{E}+06$ \\
\hline 48 & Bellmore Creek & $0.00 \mathrm{E}+00$ & $8.55 \mathrm{E}+05$ \\
\hline
\end{tabular}




\section{Limitations of Analysis}

Limitations of the regional groundwater flow model for Long Island are described by Buxton and Smolensky (1999). Limitations of applying particle-tracking analysis to the regional groundwater flow model for Long Island are briefly discussed by Buxton and others (1991). The limitations of the MODPATH version 6 particle-tracking method are discussed in general in Pollock (2012). A limitation of the analysis of the study in this report is the coarse nature of the model grid (4,000-foot cell size, and four layers of variable thickness) of the hydrologic conditions from 1968 to 1983 . The steady-state condition from 1968 to 1983 simulated in this report represents a period that ended several decades ago; the hydrologic changes that have affected Long Island since then are not accounted for in the model and constitute a further limitation of the analysis in this report.

The effects of lumping well pumping and stream outflow into a single boundary-condition representation as in the regional groundwater model of hydrologic conditions from 1968 to 1983 may be evaluated through a comparison of weak-sink particle-tracking approaches. An alternative simulation was run where particles were terminated at weaksink outflow boundary cells. This particle-tracking analysis (figs. 4 and 5) resulted in many more areas contributing groundwater representing outflow to freshwater bodies than in the first simulation. Because it is not tractable to differentiate between weak-sink conditions caused by pumping wells from those caused by receiving water bodies, there were also many particle terminations at pumping wells. For example, in Riverhead, shallow agricultural pumping wells form a checkered pattern in the areas contributing groundwater delineated for Flanders Bay (fig. 4B, index -37). Particle paths started within weak-sink flow model cells that are not assigned a receiving water body index (and the particles are captured by pumped wells) immediately terminate without an ending zone assignment. Explicit representation of weak-sink mechanisms may be useful in identifying areas contributing groundwater to freshwater receiving bodies but also increases granularity in the model-grid due to artifacts related to the representation of boundary conditions.

The eastern Jamaica Bay coastline provides an example of the limitation of weak sinks in particle tracking analysis of areas contributing water. Nearby this coast, there is an area that is so strongly affected by public-supply well pumpage that a large cone of depression has formed with water levels below sea level (Buxton and Smolensky, 1999). Due to a landward hydraulic gradient, model cells representing the coastline may become weak sinks of outflow, where some water outflows to a constant head boundary, but some water flows toward other model cells and is ultimately captured by pumping wells. If particles are allowed to pass through weak sinks, they may pass on towards pumping wells and not enter into the delineation of an area contributing groundwater (only areas associated with receiving water bodies are delineated, not areas associated with well capture). Thus, along a reach of the Jamaica Bay coastline, there is a gap in the area contributing groundwater delineation (fig. $2 A$, index -16) that may be generally interpreted as a well capture zone. However, if particles are stopped at weak sink coastline cells, then they may enter into the delineation of an area contributing groundwater to a receiving surface water body. Thus the gap in the area contributing groundwater delineation that was present with particles stopping at strong sinks (fig. $2 A$, index -16 ) is closed during the simulation with particles stopping at weak sinks (fig. $4 A$, index -16 ).

Particles generally terminate at weak sinks earlier (quicker travel times) than if the weak sink option is not used. In Brooklyn, travel times are similar for both particle-tracking analyses as can been seen by comparing the sizes and shapes of the greater than 1,000-year zones of figures 3 and 5 due to the lack of weak sinks there. In the alternative analysis, travel times for Nassau and Suffolk Counties are shorter than the 1,000-year timeframe and have many weak sinks.

Additional considerations are necessary when particle tracking methods are used to estimate nitrogen loading mechanisms. Uncertainties include the effects of dispersion on transport of mass, and the possibility of processes affecting nitrogen transport that are not accounted for in the groundwater flow model (Walter, 2008). 


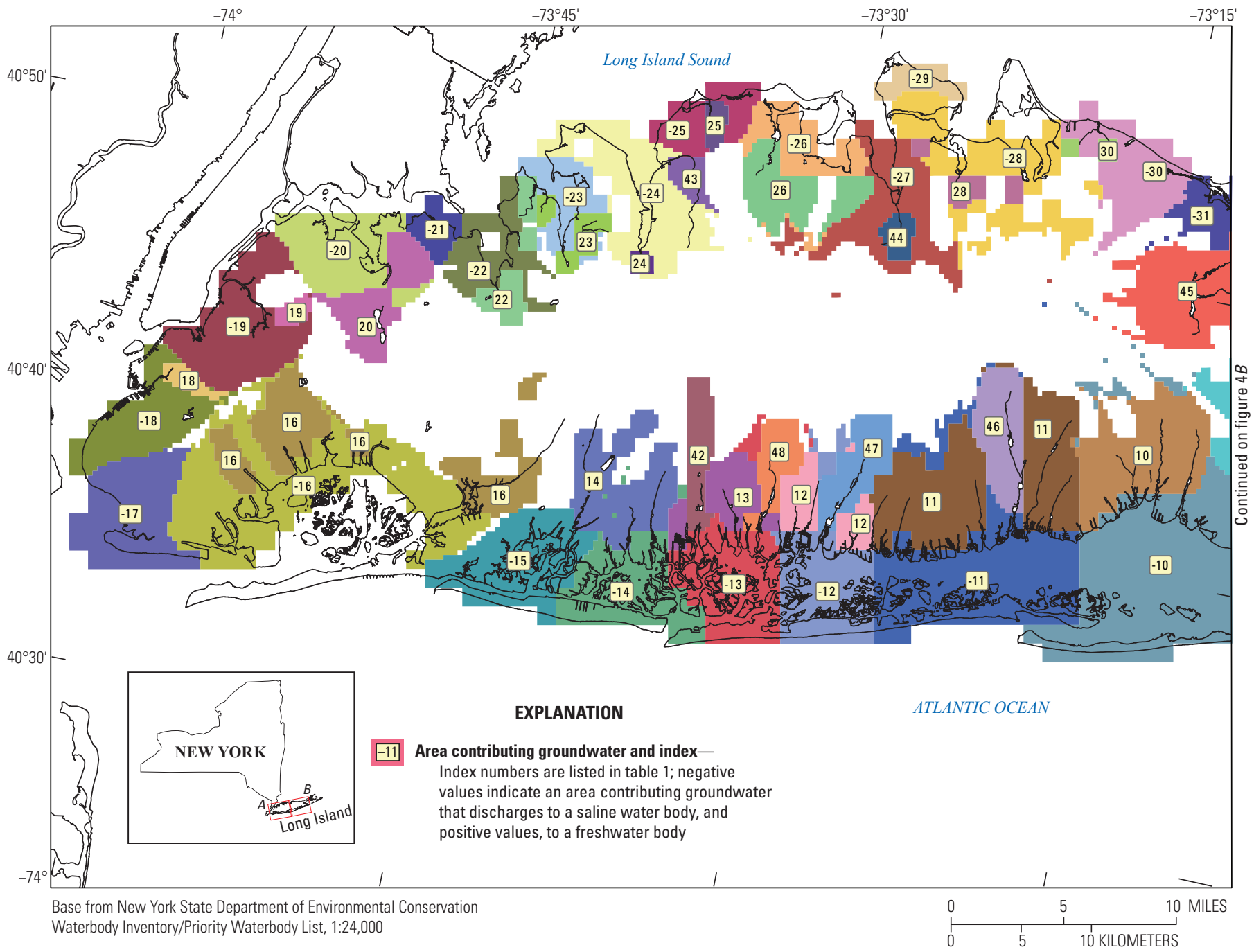

Figure 4. Areas contributing groundwater by type of receiving water body simulated by flow model of hydrologic conditions from 1968 to 1983 with particles stopping at weak sinks on $A$, western and $B$, eastern Long Island, New York. Entire map in full scale available for download at http://dx.doi.org/10.3133/sir20165138. 


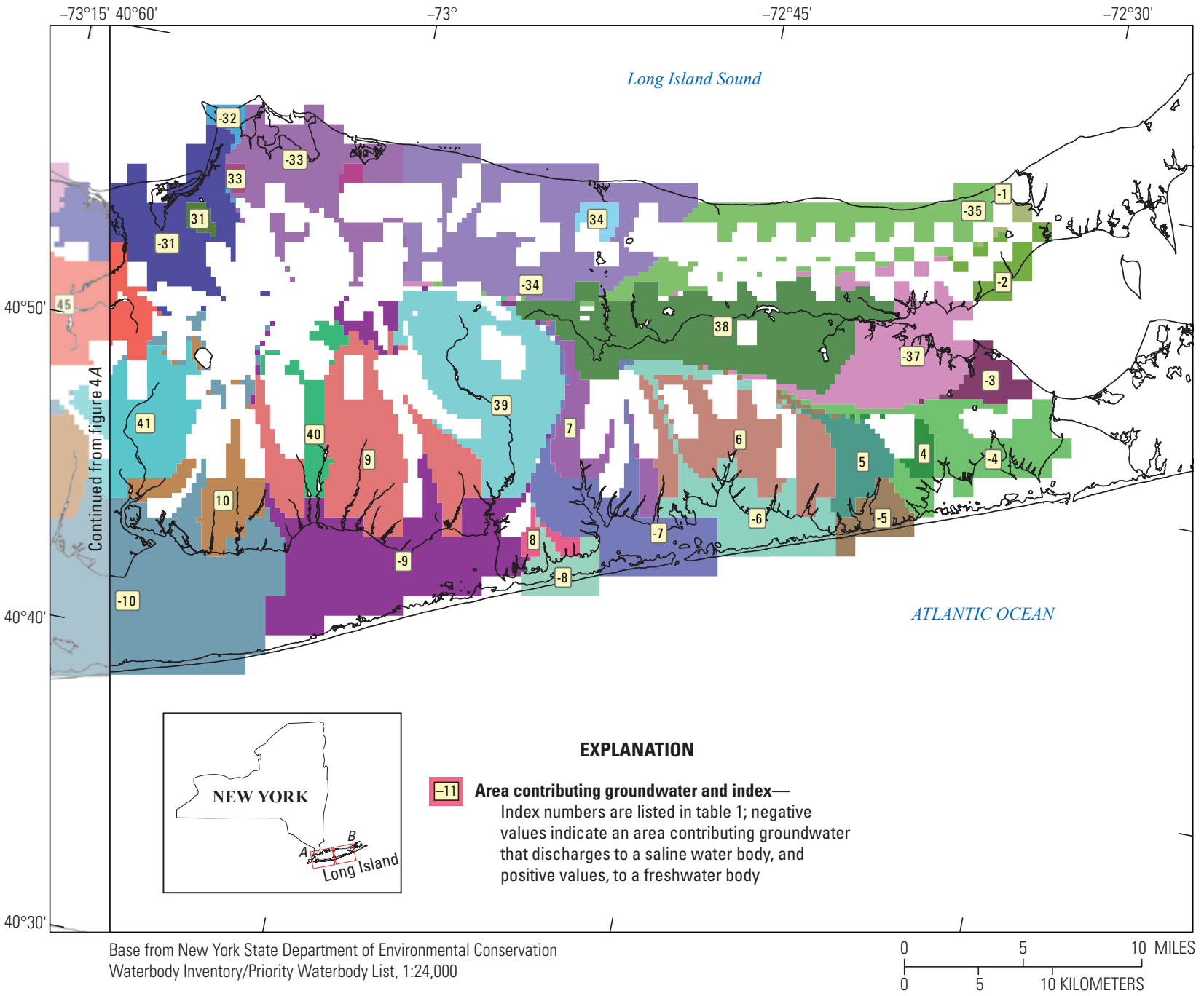

Figure 4. Areas contributing groundwater by type of receiving water body simulated by flow model of hydrologic conditions from 1968 to 1983 with particles stopping at weak sinks on $A$, western and $B$, eastern Long Island, New York. Entire map in full scale available for download at http://dx.doi.org/10.3133/sir20165138.-Continued 


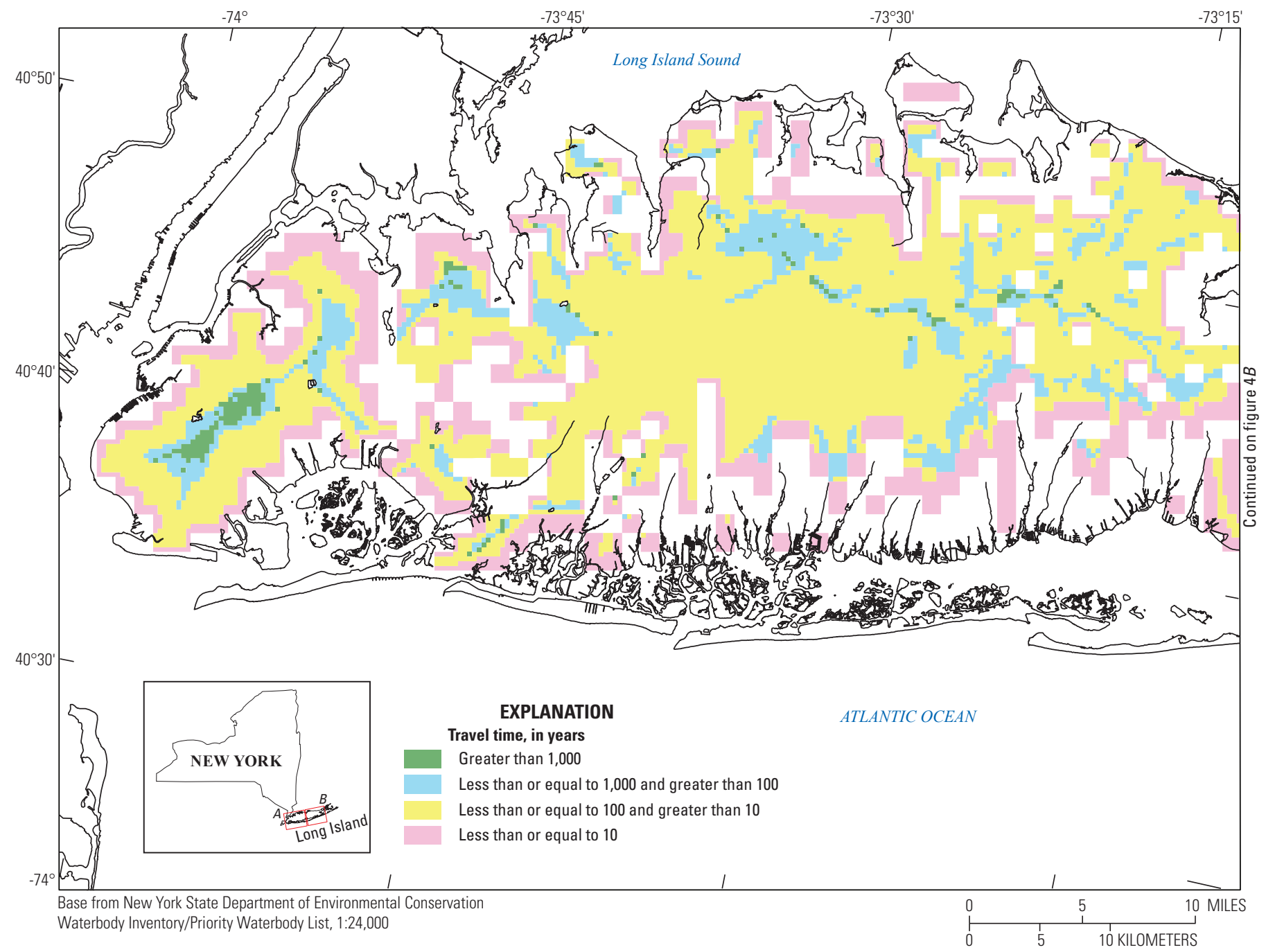

Figure 5. Travel time simulated by flow model of hydrologic conditions from 1968 to 1983 with particles stopping at weak sinks on $A$, western and $B$, eastern Long Island, New York. Entire map in full scale available for download at http://dx.doi.org/10.3133/sir20165138. 


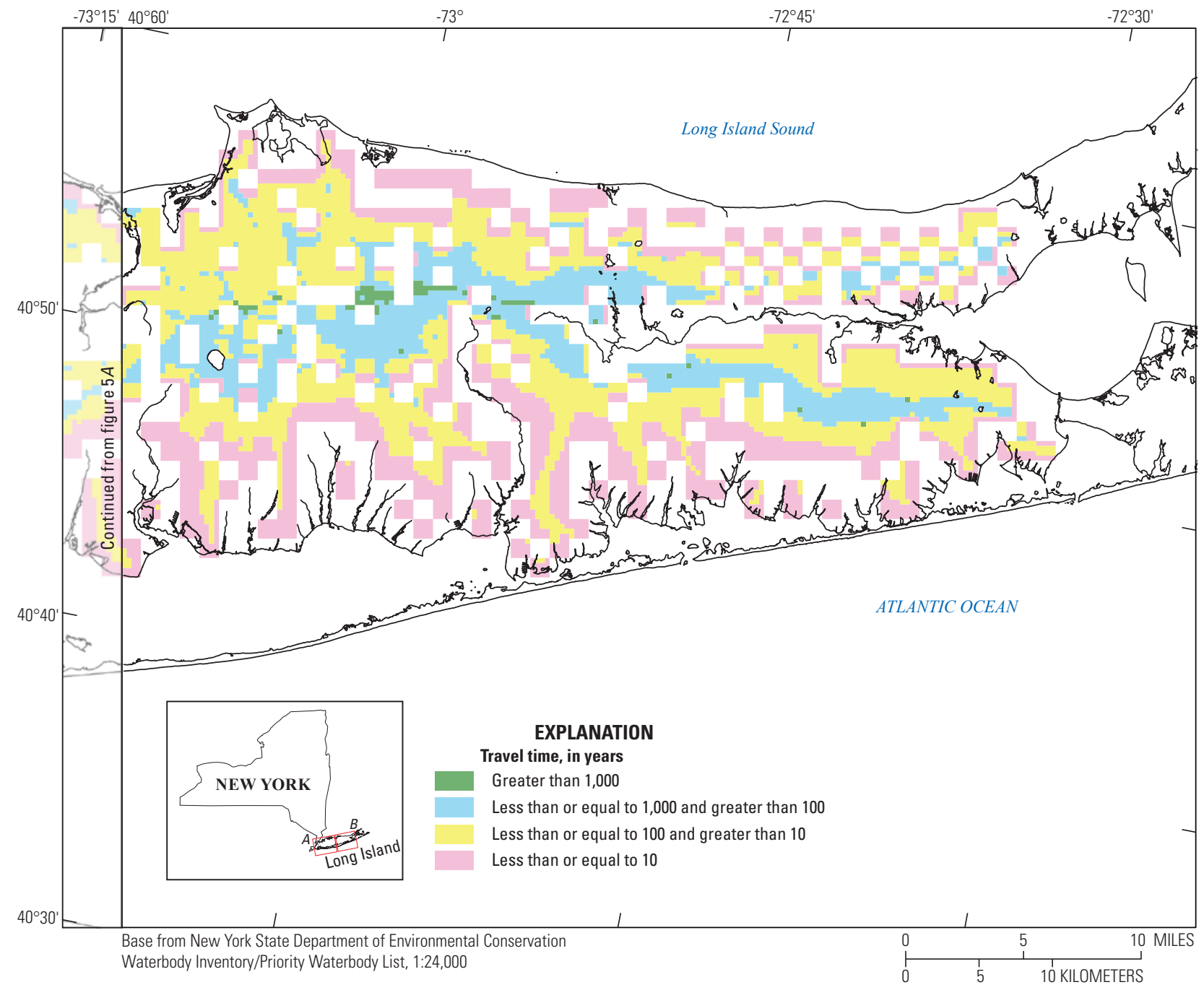

Figure 5. Travel time simulated by flow model of hydrologic conditions from 1968 to 1983 with particles stopping at weak sinks on $A$, western and $B$, eastern Long Island, New York. Entire map in full scale available for download at http://dx.doi.org/10.3133/ sir20165138.-Continued 


\section{Summary and Conclusions}

The coastal water bodies of Long Island, New York, receive nitrogen-laden freshwater from surface-water and groundwater inflows as well as from tidal exchanges of saltwater. To aid in developing informed strategies to address nitrogen loading to these systems, the U.S. Geological Survey and the New York State Department of Environmental Conservation initiated a program to delineate a comprehensive dataset of groundwater recharge areas (or areas contributing groundwater), travel times, and outflows to streams and saline embayments on Long Island. Estimating nitrogen-loading rates to coastal water bodies requires an understanding of groundwater recharge to water bodies, including the locations of areas that contribute recharge to a coastal water body, the travel times of water through the aquifers between the water table recharge and outflow locations, and the effects of surface water bodies — ponds and streams - on both recharge areas and travel times. Most of the freshwater that flows to coastal water bodies on Long Island comes from groundwater; as such, surface drainages cannot be used to delineate areas at the land surface that contribute water to a coastal water body. Delineating areas contributing groundwater under such flow regimes requires evaluation of three-dimensional groundwaterflow patterns in the aquifer, which, on Long Island, are affected primarily by the geometry of the coast and the locations of ponds and streams. As a result, recharge of areas contributing groundwater to coastal water bodies consists of multiple components and has complex travel time patterns.

This report coarsely delineates a set of 48 areas contributing groundwater using a regional MODFLOW model of hydrologic conditions from 1968 to 1983. Sixteen particle starting points were evenly spaced within each of the 4,000 - by 4,000-foot model cells receiving recharge at the water table. Simulated tracking times and ending zones were dissolved into discrete regions of similar travel time (less than or equal to 10 years, greater than 10 years and less than or equal to 100 years, greater than 100 years and less than or equal to 1,000 years, and greater than 1,000 years). End zones were established for coastlines and streams, and the sum of groundwater outflow for each ending zone was estimated. The size and shape of the resulting areas contributing groundwater are a function of the amount of outflow to the receiving water body and the hydraulic properties of the groundwater flow model.

\section{References Cited}

Buxton, H.T., Reilly, T.E., Pollock, D.W., and Smolensky, D.A., 1991, Particle tracking analysis of recharge areas on Long Island, New York: Groundwater, v. 29, no. 1, p. 63-71. [Also available at http://dx.doi.org/10.1111/j.1745-6584.1991.tb00498.x.]
Buxton, H.T., and Smolensky, D.A., 1999, Simulation analysis of the development of the groundwater flow system of Long Island, New York: U.S. Geological Survey Water-Resources Investigations Report 98-4069, 39 p. [Also available at https://pubs.er.usgs.gov/publication/wri984069.]

Camp Dresser \& McKee, Inc., 2003, Long Island source water assessment summary report: New York State Department of Health Center for Environmental Health [variously paged].

DeSimone, L.A., McMahon, P.B., and Rosen, M.R., 2014, The quality of our Nation's waters - Water quality in principal aquifers of the United States, 1991-2010: U.S. Geological Survey Circular 1360, 151 p., http://dx.doi.org/10.3133/ $\operatorname{cir} 1360$.

Harbaugh, A.W., 2005, MODFLOW-2005, the U.S. Geological Survey modular ground-water model-The groundwater flow process: U.S. Geological Survey Techniques and Methods, book 6, chap. A16 [variously paged], accessed June 1, 2016, at https://pubs.er.usgs.gov/publication/ tm6A16.

Harbaugh, A.W., Banta, E.R., Hill, M.C., and McDonald, M.G., 2000, MODFLOW-2000, the U.S. Geological Survey modular ground-water model-User guide to modularization concepts and the ground-water flow process: U.S. Geological Survey Open-File Report 00-92, 121 p.

Masterson, J.P., Pope, J.P., Fienen, M.N., Monti, Jack, Jr., Nardi, M.R., and Finkelstein, J.S., 2016, Assessment of groundwater availability in the Northern Atlantic Coastal Plain aquifer system from Long Island, New York, to North Carolina: U.S. Geological Survey Professional Paper 1829, 76 p., accessed August 31, 2016, at http://dx.doi.org/10.3133/pp1829.

Misut, P.E., and Monti, Jack, Jr., 2016, MODFLOW-2005 and MODPATH6 models used to delineate areas contributing groundwater to selected surface receiving waters for long-term average hydrologic stress conditions from 1968 to 1983, Long Island, New York: U.S. Geological Survey data release, accessed September 2016, at http://dx.doi.org/10.5066/F7TB151D.

New York State Department of Environmental Conservation, 2009, Section 305(b) assessment methodology: New York State Department of Environmental Conservation consolidated assessment and listing methodology, 24 p., accessed August 2016, at http://www.dec.ny.gov/docs/ water_pdf/asmtmeth09.pdf.

Pollock, D.W., 2012, User guide for MODPATH version 6 A particle-tracking model for MODFLOW: U.S. Geological Survey Techniques and Methods, book 6, chap. A41, 58 p. [Also available at https://pubs.er.usgs.gov/publication/ tm6A41.] 
U.S. Geological Survey, 2016, Hydrologic information and data for New York: U.S. Geological Survey Web page, accessed August 2016, at http://ny.water.usgs.gov/infodata/.

Walter, D.A., 2008, Use of numerical models to simulate transport of sewage-derived nitrate in a coastal aquifer, central and western Cape Cod, Massachusetts: U.S. Geological Survey Scientific Investigations Report 2007-5259, 41 p.

Winston, R.B., 2009, ModelMuse-A graphical user interface for MODFLOW-2005 and PHAST: U.S. Geological Survey Techniques and Methods, book 6, chap. A29, 52 p. [Also available at https://pubs.er.usgs.gov/publication/tm6A29.] 



\section{Glossary}

binary input and output file Computer file stored in a binary format, typically using only the characters " 0 " and " 1 ;" this format is readable only by a machine and requires rules to decipher.

confining unit A layer of sediment or lithologic material of low permeability that impedes the movement of water into and (or) out of an aquifer.

constant flux boundary A boundary condition in a model where an amount of inflow or outflow is fixed, requiring a variable amount of water to flow towards or away from the location to satisfy the condition. Simulated head at constant flux boundary condition may vary.

constant head boundary A boundary condition in a model where head is fixed, requiring a variable amount of water to flow towards or away from the location to satisfy the condition.

ending zone A model region where the pathline of a particle terminates.

finite difference technique A numerical method to solve mathematical problems through use of a rectangular grid.

forward particle tracking A method in which particles are tracked forward through time.

glacial moraine A glacial deposit upgradient of the ice limit of a glaciation event, typically of relatively low hydraulic conductivity.

glacial outwash plain A glacial deposit downgradient of the ice limit of a glaciation event, typically of relatively high hydraulic conductivity.

graphical user interface Graphical interface that allows a user to interact with software by providing controls for preprocessing and postprocessing model simulations, allowing access to the data that were used to create the model.

Lloyd aquifer The deepest and oldest of the aquifers on Long Island, composed of fine to coarse sand and gravel with a clayey matrix and some layers of silty or solid clay. The aquifer was derived from stream erosion of areas to the north and west of Long Island during the late Cretaceous Period.

Magothy aquifer The largest of the aquifers on Long Island, composed of river delta sediments that were deposited during the late Cretaceous Period. Fine to medium sand is interbedded with clay and sandy clay of moderate permeability and silt and clay of low to very low permeability. The basal zone commonly contains coarse sand and gravel.

model archive A set of files that may be used to reproduce a model simulation.

open-source Code and software that can used, changed, and shared freely by anyone.

partial differential equation A differential equation that contains unknown multivariable functions and their partial derivative.

particle-tracking analysis Water particles tracked through time under the assumption that they are transported by advection using a simulated flow field. Particles can be tracked either forward or backward in time. This qualitative approach does not conserve mass.

Raritan confining unit Underlies the Magothy aquifer, derived from stream erosion of areas to the north and west during the late Cretaceous Period.

starting point In a forward particle-tracking analysis, the point of origin of the particle's pathline.

strong sink cell In a particle-tracking analysis, a cell where 100 percent of the total flow in the cell is removed by the simulated boundary. A decision may be made as to whether to allow the particle to track through the cell or to terminate the path.

tracking time In a forward particle-tracking analysis, the amount of time elapsed between particle starting and particle termination.

travel time The length of time for water to travel from its recharge location at the water table to a well, pond, stream, or coastal water body. 
upper glacial aquifer An unconfined aquifer directly underlying the ground surface of Long Island. The upper glacial aquifer was formed during the last ice age.

water table The top of an unconfined aquifer below which the pore spaces are generally saturated; the level in the saturated zone.

weak sink cell In a particle-tracking analysis, a cell where there is partial throughput of water. A decision may be made as to whether to allow the particle to track through the cell or to terminate the path. 
For additional information write to:

Director, New York Water Science Center

U.S. Geological Survey

2045 Route 112, Building 4

Coram, NY 11727

Information requests:

(518) 285-5602

or visit our Web site at:

http://ny.water.usgs.gov

Publishing support by:

The Pembroke Publishing Service Center 
这 